Naqvi, S. M. (edit.), Archaean Geochemistry. Developments in Precambrian geology. 1, 375-392. Amsterdam: Elsevier.

Garde, A. A., Hall, R. P., Hughes, D. J., Jensen, S. B., Nutman, A. P. \& Stecher, O. 1983: Mapping of the Isukasia sheet, southern West Greenland. Rapp. Grønlands geol. Unders. 115, 20-29.

Hall, R. P. 1980: The tholeiitic and komatiitic affinities of the Malene metavolcanic amphibolites from Ivisârtoq, southern West Greenland. Rapp. Grønlands geol. Unders. 97, 20 pp.

Hall, R. P. 1981: The Archaean geology of Ivisârtoq, inner Godthåbsfjord, southern West Greenland. Unpubl. Ph. D. thesis, Council for National Academic Awards, Portsmouth Polytechnic.

Mercier, J-C. C. \& Nicolas, A. 1975: Textures and fabrics of upper-mantle peridotites as illustrated by xenoliths from basalts. J. Petrol. 16, 454-487.

Nicolas, A., Boudier, F. \& Bouchez, J. L. 1980: Interpretation of peridotite structures from ophiolitic and oceanic environments. Am. J. Sci. 280-A, 192-210.

Nutman, A. P., Bridgwater, D., Dimroth, E., Gill, R. C. O. \& Rosing, M. 1983: Early (3700 Ma) Archaean rocks of the Isua supracrustal belt and adjacent gneisses. Rapp. Grønlands geol. Unders. 112, 5-22.

Rothstein, A. T. V. 1977: The distribution and origin of primary textures in the Lizard peridotite, Cornwall. Proc. Geol. Assoc. 88, 93-105.

Streckeisen, A. 1976: To each plutonic rock its proper name. Earth-Sci. Rev. 12, 1-33.

Department of Geology,

The University,

Exeter EX4 $4 Q E$,

U. K.

\title{
An iron-formation in the Precambrian Tartoq Group, South-West Greenland
}

\author{
Peter W. Uitterdijk Appel
}

During the 1950s and early 1960s the Ivigtut area was mapped by the Geological Survey of Greenland (GGU), as part of GGUs systematic mapping programme. Detailed work was carried out on the two supracrustal units in the area, and the relative age relationship of the two units was established. The younger Ketilidian supracrustal rocks outcrop in the inland area, close to the Inland Ice, and the older Tartoq Group supracrustal rocks are found in and around Sermiligârssuk fjord. In the early 1970s Renzy Mines Ltd. conducted a mineral exploration programme in the area, during which arsenopyrite-pyrite mineralisations were found in the Tartoq Group supracrustals (Appel \& Secher, 1984), and a banded ironformation was discovered in the Ketilidian supracrustal rocks (Appel, 1974). During the 1983 field season two teams from GGU undertook field work in the area, as a result of which a banded iron-formation was discovered in the Tartoq Group supracrustal rocks. 


\section{General geology}

The gneisses in the Sermiligârssuk area are of granodioritic composition with varying amounts of leucocratic veins, grading into migmatites. Within these gneisses broad zones and smaller enclaves of supracrustal rocks occur, collectively termed the Tartoq Group. These occurrences are presumed to be remnants of one large supracrustal belt (Higgins \& Bondesen, 1966; Windley et al., 1966). The contacts between the Tartoq Group and the surrounding gneisses are either tectonic or migmatites (Windley et al., 1966). It is thus not possible to establish age relationships between the gneisses and the Tartoq Group supracrustal rocks. The few isotopic data available from the area indicate a minimum age for the gneisses of $2980 \pm 10$ m.y., and a maximum age of 3500 m.y. (Kanasewich \& Slawson, 1964; Ulrych, 1964).

Ketilidian rocks unconformably overlie the gneisses and the Tartoq Group in the eastern part of the area. The Ketilidian sequence comprises virtually unmetamorphosed, and only slightly deformed, sedimentary and volcanic rocks with an exposed thickness of up to $4400 \mathrm{~m}$ (Higgins, 1970). K/Ar mineral age determinations suggest that the Ketilidian supracrustal rocks are older than 1850 m.y. (Larsen, 1971).

\section{The Tartoq Group supracrustal rocks}

The Tartoq Group has been described by Weidmann (1964), Higgins \& Bondesen (1966) and Higgins (1968), and summarised by Berthelsen \& Henriksen (1975). The most interesting area in the context of this paper, the Iterdlak area (fig. 33) has been described by Micheelsen (1955) and Higgins (1968).

The Tartoq Group has been strongly deformed and metamorphosed, as a result of which most facing criteria have been obliterated. A detailed stratigraphy is thus difficult to establish. Berthelsen \& Henriksen (1975) divided the supracrustals into a lower mixed sedimentary-volcanic part and an upper mainly volcanic part. Estimated thicknesses are of the order of $2000 \mathrm{~m}$. The matasedimentary layers of the lower part are slightly rusty to very rusty calcareous-siliceous schists and grey to white schists. The rusty schists contain varying amounts of chlorite, epidote, talc and small amounts of disseminated sulphides. Locally a thin spectacular orange coloured dolomite horizon occurs. The white to grey schists consist of quartz, K-feldspar and muscovite. In the Iterdlak area a thin conglomerate with elongated quartz-feldspar pebbles up to $5 \mathrm{~cm}$ across is seen. In the lower mixed sedimentary-volcanic part, horizons of banded iron-formation occur (see below).

The basic rocks are generally highly schistose, but locally pillow structures can be observed. Some more massive basic rocks also occur, and presumably represent volcanic lavas and intrusive sills. A few layered pyroclastic rocks are present, while lens-shaped ultrabasic rocks are abundant.

\section{The Tartoq Group iron-formations}

Horizons of iron-formation have been found in several of the Tartoq Group outcrops (fig. 33). Those in the inner Sermiligârssuk area were found by K. Secher (personal communication), while those in the Iterdlak area were found by the author. The following description is concentrated on the iron-formations in the Iterdlak and Tartoq areas. The banded iron- 


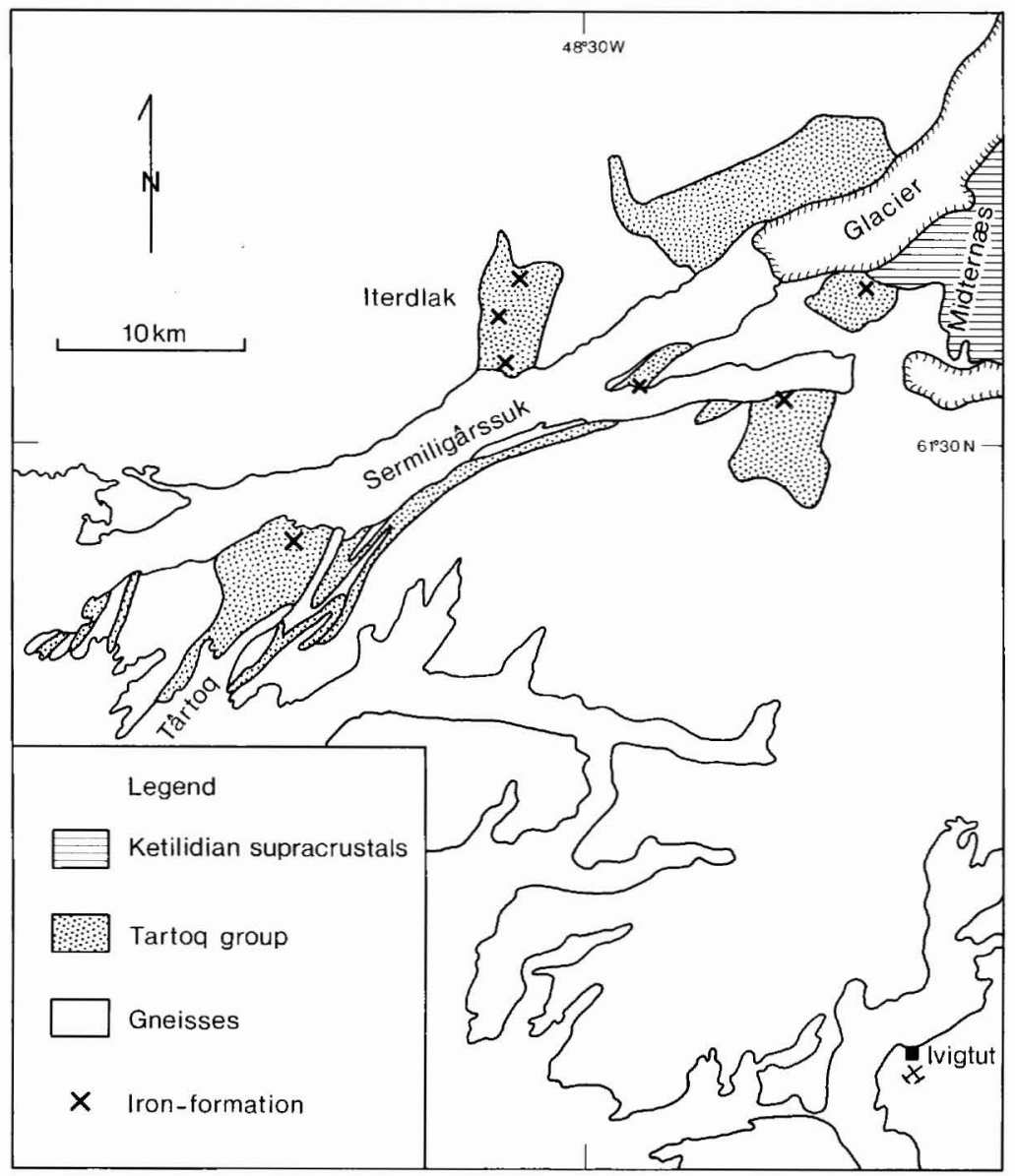

Fig. 33. Geological sketch map of the Sermiligârssuk area showing the locations of the iron-formations.

formations in the Tartoq Group are very similar to Precambrian iron-formations found elsewhere.

Oxide facies iron-formation is found in the northern part of the Iterdlak area. It is well banded with alternating quartz and magnetite bands. The banding is very regular, and the thickness of the bands ranges from a few millimetres up to $1 \mathrm{~cm}$. Parts of the iron-formation are slightly rusty due to scattered pyrite crystals (up to $1 \mathrm{~cm}$ across), and locally there are minor amounts of chalcopyrite. Within the oxide facies iron-formation thin horizons of sulphide facies iron-formation were observed. They consist of thin bands of massive pyrite alternating with thin quartz bands. Locally the quartz bands are rich in fuchsite. The exposed width of the oxide facies iron-formation with intercalated sulphide facies layers is about $\mathbf{5 0}$ $\mathrm{m}$. Strong isoclinal folding has caused repetition of the horizons, so the original width of the iron-formation was probably not more than 5-10 m. The strike length is of the order of $50 \mathrm{~m}$. 
Towards the north the iron-formation is limited by a fold closure, while towards the south erosion has removed the continuation of the horizon.

Sulphide facies iron-formations have been found in two places in the Iterdlak area, and also occur in the Tartoq area (fig. 33).

The sulphide facies iron-formation in the central part of the Iterdlak area consists of pyritic layers alternating with quartz-rich layers. The pyritic layers range from a few centimetres to $0.5 \mathrm{~m}$ in width, whereas the quartz-rich layers rarely exceed $10 \mathrm{~cm}$ in width. The quartz-rich layers often contain high amounts of fuchsite, and fuchsite is locally seen as scattered grains in the pyrite-rich layers. This sulphide facies horizon has an exposed width of more than $50 \mathrm{~m}$ and can be traced discontinuously for $100 \mathrm{~m}$ along strike.

In the coastal area of Iterdlak (fig. 33) an unusual type of sulphide facies was observed. It consists of a very rusty sequence of mica schists with lenses and thin layers of massive pyrite and quartz. The pyritic and quartz-rich layers are up to $5 \mathrm{~cm}$ wide and 20 to $30 \mathrm{~cm}$ long, and are arranged parallel to the schistosity of the rusty schists. The whole sequence is about $5 \mathrm{~m}$ wide, and can be traced at intervals for about $100 \mathrm{~m}$.

A special type of sulphide facies iron-formation seen in the Tartoq area has recently been described by Appel \& Secher (1984), and only a brief account will be given here. This ironformation consists of almost massive pyrite and arsenopyrite with small amounts of quartz, locally with chalcopyrite and tennantite. Two horizons up to $0.5 \mathrm{~m}$ wide and about $1 \mathrm{~m}$ apart can be traced at intervals for more than $1 \mathrm{~km}$ along strike. These horizons of iron-formation contain ore grade amounts of gold and copper.

\section{Discussion}

Previous field work in the area revealed the existence of extensive rust zones, where the rust was caused by small amounts of disseminated pyrite; but horizons of iron-formation were not recorded. We have now found genuine horizons of iron-formation, comprising typical quartz-magnetite banded iron-formation and sulphide facies iron-formation. Carbonate and silicate facies have not been found yet. The size of the horizons is not impressive, but the existence of an iron-formation in the Tartoq Group is not unexpected since ironformations are found in virtually all supracrustal belts. It was previously suggested that the absence of iron-formation was due to the depositional environment during deposition of the Tartoq Group supracrustal rocks. However, it is now clear that an iron-formation, although small, does exist in the Tartoq Group. It is therefore not necessary to invoke a special depositional environment during the formation of the Tartoq Group supracrustal rocks.

An interesting implication of the discovery of an iron-formation in the Tartoq Group is that the gold potential of the area is greatly increased since iron-formations elsewhere are known to carry gold (Fripp, 1976). Furthermore, there seems to be a good chance of finding gold in the Ketilidian basal conglomerate, as fuchsite pebbles and pyrite are commonly found in it. They are most likely derived from the Tartoq Group iron-formation. 


\title{
References
}

Appel, P. W. U. 1974: On an unmetamorphosed iron-formation in the early Precambrian of South-West Greenland. Miner. Deposita 9, 75-82.

Appel, P. W. U. \& Secher, K. 1984: On a gold mineralization in the Precambrian Tartoq Group, SouthWest Greenland. J. geol. Soc. Lond. 141, 273-278.

Berthelsen, A. \& Henriksen, N. 1975: Geological map of Greenland 1:100 000 Ivigtut 61 V. 1 Syd. Copenhagen: Grønlands geol. Unders. (also Meddr Grønland 186, 1) 169 pp.

Fripp, R. E. P. 1976: Stratabound gold deposits in Archean banded iron-formation, Rhodesia. Econ. Geol. 71, 58-75.

Higgins, A. K. 1968: The Tartoq Group on Nuna qaqertoq and in the Iterdlak area, South-West Greenland. Rapp. Grønlands geol. Unders. 17, 17 pp.

Higgins, A. K. 1970: The stratigraphy and structure of the Ketilidian rocks of Midternæs, South-West Greenland. Bull. Grønlands geol. Unders. 87 (also Meddr Grønland 189, 2) 96 pp.

Higgins, A. K. \& Bondesen, E. 1966: Supracrustals of pre-Ketilidian age (the Tartoq Group) and their relationships with Ketilidian supracrustals in the Ivigtut region, South-West Greenland. Rapp. Grønlands geol. Unders. 8, $21 \mathrm{pp}$.

Kanasevich, E. R. \& Slawson, W. F. 1964: Precision intercomparisons of lead isotope ratios: Ivigtut, Greenland. Geochim. cosmochim. Acta 28, 541-549.

Larsen, O. 1971: Preliminary report on K/Ar dating in the southeastern part of the Ivigtut region. Rapp. Grønlands geol. Unders. 35, 49-52.

Micheelsen, H. 1955: Rapport over det geologiske feltarbejde i Sermiligârssuk i sommeren 1955. Unpubl. intern. GGU rep., 14 pp.

Ulrych, T. J. 1964: The anomalous nature of Ivigtut lead. Geochim. cosmochim. Acta 28, 1389-1396.

Weidmann, M. 1964: Géologie de la région située entre Tigssaluk fjord et Sermiligârssuk fjord (partie médiane), SW-Groenland. Bull. Grønlands geol. Unders. 40 (also Meddr Grønland 169, 1), 146 pp.

Windley, B. F., Henriksen, N., Higgins, A. K., Bondesen, E. \& Jensen, S. B. 1966: Some border relations between supracrustal and infracrustal rocks in South-West Greenland. Rapp. Grønlands geol. Unders. 9, 43 pp.

\section{Geological and radiometric mapping of the Motzfeldt Centre of the Igaliko Complex, South Greenland}

\author{
Tapani Tukiainen, Colin Bradshaw and C. Henry Emeleus
}

The geological and radiometric mapping of the Motzfeldt Centre was commenced in 1982 as part of the extended Syduran project under the Ministry of Energy's Research Programmes of 1981 and 1982 (Armour-Brown et al., 1983). The purpose of the study was to make a detailed geological and radiometric map of the centre with a view to provide a reliable reference framework for the evaluation of the economic mineral potential of the centre where an extensive $\mathrm{Th}-\mathrm{U}-\mathrm{Zr}-\mathrm{Nb}-\mathrm{REE}$ mineralisation was discovered by the reconnaissance surveys of the Syduran project, which was partly financed by the European 